\title{
Front Matter: Volume 8844
}

, "Front Matter: Volume 8844," Proc. SPIE 8844, Optical System Alignment, Tolerancing, and Verification VII, 884401 (18 October 2013); doi:

$10.1117 / 12.2046467$

SPIE Event: SPIE Optical Engineering + Applications, 2013, San Diego, California, SPIE. United States 


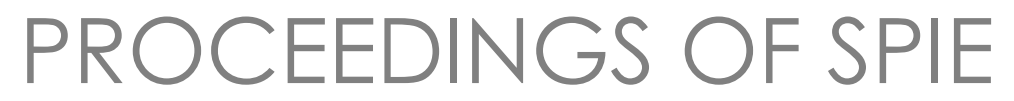

\section{Optical System Alignment, Tolerancing, and Verification VII}

José Sasián

Richard N. Youngworth

Editors

25-26 August 2013

San Diego, California, United States

Sponsored and Published by

SPIE 
The papers included in this volume were part of the technical conference cited on the cover and title page. Papers were selected and subject to review by the editors and conference program committee. Some conference presentations may not be available for publication. The papers published in these proceedings reflect the work and thoughts of the authors and are published herein as submitted. The publisher is not responsible for the validity of the information or for any outcomes resulting from reliance thereon.

Please use the following format to cite material from this book:

Author(s), "Title of Paper," in Optical System Alignment, Tolerancing, and Verification VII, edited by José Sasián, Richard N. Youngworth, Proceedings of SPIE Vol. 8844 (SPIE, Bellingham, WA, 2013) Article CID Number.

ISSN: 0277-786X

ISBN: 9780819496942

Published by

SPIE

P.O. Box 10, Bellingham, Washington 98227-0010 USA

Telephone +1 3606763290 (Pacific Time) · Fax +1 3606471445

SPIE.org

Copyright (C) 2013, Society of Photo-Optical Instrumentation Engineers.

Copying of material in this book for internal or personal use, or for the internal or personal use of specific clients, beyond the fair use provisions granted by the U.S. Copyright Law is authorized by SPIE subject to payment of copying fees. The Transactional Reporting Service base fee for this volume is $\$ 18.00$ per article (or portion thereof), which should be paid directly to the Copyright Clearance Center (CCC), 222 Rosewood Drive, Danvers, MA 01923. Payment may also be made electronically through CCC Online at copyright.com. Other copying for republication, resale, advertising or promotion, or any form of systematic or multiple reproduction of any material in this book is prohibited except with permission in writing from the publisher. The CCC fee code is 0277-786X/13/\$18.00.

Printed in the United States of America.

Publication of record for individual papers is online in the SPIE Digital Library.

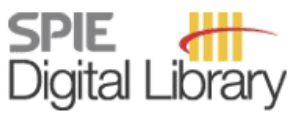

SPIEDigitalLibrary.org

Paper Numbering: Proceedings of SPIE follow an e-First publication model, with papers published first online and then in print and on CD-ROM. Papers are published as they are submitted and meet publication criteria. A unique, consistent, permanent citation identifier (CID) number is assigned to each article at the time of the first publication. Utilization of CIDs allows articles to be fully citable as soon as they are published online, and connects the same identifier to all online, print, and electronic versions of the publication. SPIE uses a six-digit CID article numbering system in which:

- The first four digits correspond to the SPIE volume number.

- The last two digits indicate publication order within the volume using a Base 36 numbering

system employing both numerals and letters. These two-number sets start with 00, 01, 02, 03, 04, $05,06,07,08,09,0 A, 0 B \ldots$. 0Z, followed by 10-1Z, 20-2Z, etc.

The CID Number appears on each page of the manuscript. The complete citation is used on the first page, and an abbreviated version on subsequent pages. Numbers in the index correspond to the last two digits of the six-digit CID Number. 


\title{
Contents
}

\author{
$\checkmark \quad$ Conference Committee \\ vii Introduction
}

\section{SESSION 1}

\section{TOLERANCING AND INSTRUMENT ALIGNMENT}

884402 Optomechanical considerations for realistic tolerancing [8844-1]

E. Herman, J. Sasián, College of Optical Sciences, The Univ. of Arizona (United States);

R. N. Youngworth, Riyo LLC (United States)

884403 Alignment of four-mirror wide field corrector for the Hobby-Eberly Telescope (Invited Paper) [8844-2]

C. J. Oh, E. H. Frater, L. Coyle, M. Dubin, A. Lowman, C. Zhao, J. H. Burge, College of Optical Sciences, The Univ. of Arizona (United States)

884404 Secondary color correction and tolerance sensitivity: What can you get away with? (Invited Paper) [8844-3]

J. R. Rogers, Synopsys, Inc. (United States)

\section{SESSION 2 ALIGNMENT AND OPTOMECHANICS}

884406 Optical alignment of the Global Precipitation Measurements (GPM) star trackers [8844-5] S. Hetherington, NASA Goddard Space Flight Ctr. (United States); D. Osgood, J. McMann, V. Roberts, J. Gill, K. McLean, Qinetiq North America (United States)

884407 Method of calculation and tables of optothermal coefficients and thermal diffusivities for glass [8844-22]

D. Reshidko, J. Sasián, College of Optical Sciences, The Univ. of Arizona (United States)

884408 Integration and alignment of ATLAS instrument engineering model components in Optical Development System Lab [8844-7]

T. Evans, SGT, Inc. (United States)

884409 High-power laser parabola focus modelling at the Central Laser Facility [8844-9]

R. I. Heathcote, R. J. Clarke, T. B. Winstone, J. S. Green, Rutherford Appleton Lab. (United Kingdom) 
$8844 \mathrm{OA}$ Alignment and testing of a telecentric zoom lens used for the Cygnus $\mathrm{x}$-ray source [8844-11]

R. M. Malone, S. A. Baker, K. K. Brown, J. J. Castaneda, A. H. Curtis, National Security Technologies, LLC (United States); J. Danielson, Los Alamos National Lab. (United States);

D. W. Droemer, D. L. Esquibel, National Security Technologies, LLC (United States);

T. J. Haines, Los Alamos National Lab. (United States); J. S. Hollabaugh, R. A. Howe,

J. A. Huerta, M. I. Kaufman, National Security Technologies, LLC (United States);

N. S. P. King, Los Alamos National Lab. (United States); S. S. Lutz, K. D. McGillivray, A. Smith,

B. M. Stokes, A. Tibbitts, National Security Technologies, LLC (United States)

8844 OB Double Zernike polynomial and its application in optical alignment [8844-12]

M.-S. Tsao, C.-W. Liang, National Central Univ. (Taiwan)

8844 OC FDTD modeling of chip-to-chip waveguide coupling via optical quilt packaging [8844-13]

T. Ahmed, Univ. of Notre Dame (United States); T. Butler, Univ. of Notre Dame (United

States) and Cork Institute of Technology (Ireland); A. A. Khan, Univ. of Notre Dame (United

States); J. M. Kulick, Indiana Integrated Circuits (United States); G. H. Bernstein,

A. J. Hoffman, S. S. Howard, Univ. of Notre Dame (United States)

8844 OD Modified point diffraction interferometer to evaluate tolerances in the design of progressive addition lenses [8844-14]

S. Chamadoira, Univ. de Santiago de Compostela (Spain); J. Sasian, College of Optical Sciences, The Univ. of Arizona (United States); E. Acosta, Univ. de Santiago de Compostela (Spain)

\section{SESSION 4 VERIFICATION OF OPTICAL SYSTEMS}

$8844 \mathrm{OE}$ Discrepancies when analyzing and testing high aperture lenses with pupil aberration [8844-15]

J. R. Mulley, Melles Griot (United States)

8844 OF Highly accurate measurement of lens surface distances within optical assemblies for quality testing [8844-16]

P. Langehanenberg, A. Ruprecht, D. Off, B. Lueerss, TRIOPTICS GmbH (Germany)

8844 OG A new approach for the verification of optical systems [8844-17]

U. Siddique, V. Aravantinos, S. Tahar, Concordia Univ. (Canada)

$8844 \mathrm{OH}$ The contribution of optical methods and geodetic instruments in structural monitoring: a brief historical survey [8844-18]

G. M. T. Radulescu, A. T. G. Radulescu, Technical Univ. of Cluj Napoca (Romania)

8844 OI Development of a medium-size SWIR imaging telescope: integration, calibration, and MTF measurement [8844-20]

O. Yilmaz, O. Selimoglu, F. Turk, TÜBiTAK UZAY (Turkey)

Author Index

iv 


\section{Conference Committee}

Program Track Chairs

José Sasián, College of Optical Sciences, The University of Arizona (United States)

R. John Koshel, Photon Engineering LLC (United States) and College of Optical Sciences, The University of Arizona (United States)

\section{Conference Chairs}

José Sasián, College of Optical Sciences, The University of Arizona (United States)

Richard N. Youngworth, Riyo LLC (United States)

Conference Program Committee

Scott C. Burkhart, Lawrence Livermore National Laboratory (United States)

Matthew B. Dubin, College of Optical Sciences, The University of Arizona (United States)

Sen Han, Soochow University (China)

Marco Hanft, Carl Zeiss Jena GmbH (Germany)

Chao-Wen Liang, National Central University (Taiwan)

Norbert Lindlein, Friedrich-Alexander-Universität Erlangen-Nürnberg (Germany)

Robert M. Malone, National Security Technologies, LLC (United States)

Raymond G. OhI IV, NASA Goddard Space Flight Center (United States)

Robert E. Parks, Optical Perspectives Group, LLC (United States)

Martha Rosete-Aguilar, Universidad Nacional Autónoma de México (Mexico)

Daniel G. Smith, Nikon Research Corporation of America (United States)

Peng Su, College of Optical Sciences, The University of Arizona (United States)

Yana Z. Williams, Atlas Material Testing Technology LLC (United States)

\section{Session Chairs}

1 Tolerancing and Instrument Alignment

Robert M. Malone, National Security Technologies, LLC (United States)

2 Alignment and Optomechanics

Chao-Wen Liang, National Central University (Taiwan) 
3 Alignment, Testing, and Electro-Optics

Sen Han, Soochow University (China)

4 Verification of Optical Systems

Marco Hanft, Carl Zeiss Jena GmbH (Germany)

Proc. of SPIE Vol. $8844884401-6$

Downloaded From: https://www.spiedigitallibrary.org/conference-proceedings-of-spie on 26 Apr 2023 Terms of Use: https://www.spiedigitallibrary.org/terms-of-use 


\section{Introduction}

"Unfortunately, alignment is often considered only when one confronts the hardware. This is often too late, since system constraints have been determined."

Richard N. Shagam (Cochair of Optical Alignment), SPIE Volume 251, 1980

This year marked the seventh time this annual conference has taken place in beautiful San Diego, California, USA at SPIE Optics + Photonics 2013. This year's Optical System Alignment, Tolerancing and Verification VII conference was again very successful. The conference consisted of a day of high quality presentations, the poster session, and subsequent proceedings articles. Specifically, this year the conference had four strong sessions on tolerancing and instrument alignment, alignment and optomechanics, alignment testing and electro-optics, and verification of optical systems. We sincerely thank our invited speakers, contributed speakers, poster paper presenters, and the superb community for making the sessions and conference such a success. It is very clear that the topics covered by this conference continue to be of great interest to the optics and photonics community.

The history of SPIE conferences on Optical Alignment dates back to 1980. The most recent embodiment started in 2007 by José Sasián and Mitch Ruda. The listing of years and conference chairs for optical alignment (to 1993), optical system alignment and tolerancing (2007 to 2008), and, finally, addition of the topic of verification (2009-present) are:

- 1980 Richard N. Shagam and William C. Sweatt

- 1984 Mitch Ruda

- 1986 Mitch Ruda

- 1993 Mitch Ruda

- 2007 J. Sasián and M. Ruda

- 2008 J. Sasián and R. N. Youngworth

- 2009 J. Sasián and R. N. Youngworth

- 2010 J. Sasián and R. N. Youngworth

- 2011 J. Sasián and R. N. Youngworth

- $\quad 2012$ J. Sasián and R. N. Youngworth

- 2013 J. Sasián and R. N. Youngworth

We must of course thank our excellent program committee for continuing to promote this conference. Furthermore, we are once again quite grateful to the greater community for sharing work and participating, as interaction in this area is very beneficial in advancing our field. Finally, we thank the volunteers and SPIE staff for providing us the opportunity to cover the subjects of optical system 
alignment, tolerancing, and verification in a dedicated conference and proceedings.

This conference will continue in 2014. We encourage everyone interested in optical system alignment, tolerancing, and verification to look for the call for papers and to submit your work in early 2014. Please feel free to contact us or anyone on our program committee if you have any questions.

Finally, and most importantly in our hearts, is to mark the passing of one of the true and pure greats in the optics community, Dr. Mitch Ruda. Mitch was absolutely essential in the formation of this conference and served with us for a number of years to help highlight the importance of optical alignment. Many of us have known Mitch, worked with him, learned from him, and admired his very strong body of work. He will be greatly missed by the entire optics community.

José Sasián Richard N. Youngworth 